УдК 316.454 .5

\title{
METACOMMUNICATIVE CONTACT-ESTABLISHING TOPICALIZING QUESTIONS IN MODERN ENGLISH DIALOGIC DISCOURSE
}

\author{
I. V. GRABOVSKA, PhD in Philology, Associate Professor, \\ National University of Life and Environmental Sciences of Ukraine
}

E-mail: ivgrabovska@gmail.com

ORCID: 0000-0002-4229-6298

\begin{abstract}
The article focuses on the initial stage of the communicative contact. The paper examines functional and semantic properties of metacommunicative contactestablishing topicalizing questions as organizational means of dialogic discourse. The spectrum of metacommunicative contact-establishing themes realized by topicalizing questions in modern English dialogic discourse is suggested. Metacommunicative contactestablishing topicalizing questions regulate the flow of interaction, contribute to the realization of communicative feedback.
\end{abstract}

Keywords: metacommunicative contact-establishing topicalizing question, dialogic discourse, interaction, communicative contact, phatic communion

Introduction. Modern linguistics is characterized by an increased interest in the study of functional properties of language units. The focus is on investigation of the linguistic means that are metacommunicative in their nature, i. e., contributing to the establishment, maintainance and termination of the communicative contact between interlocutors $[1 ; 2 ; 3 ; 4 ; 5 ; 8 ; 9]$. These linguistic means are represented by interrogative sentences used in speech to mark the beginning of a communicative act in time and space and we call them metacommunicative contact-establishing questions [5]. The importance of metacommunicative contact-establishing questions in the process of communication is undisputed, since metacommunicative questions perform vital functions in everyday communication, i. e., they ensure mutual understanding, build rapport to achieve effective interpersonal interaction. One of the main metacommunicative tasks that is solved at the stage of contact-establishment is the choice of a conversational topic. Our investigation has shown that the linguistic realization of the solution of this metacommunicative task is the usage of metacommunicative contact-establishing topicalizing questions in our terminology [5].

Recent research and publications. Metacommunicative means have been the objects of investigation in connection with the study of metacommunicative questions (T. Chkhe-tiani, I. Grabovska, Ya. Gnezdilova, E. Lindstrem, S. Shymberg, Yu. Filippova), metacommunicative units (A. Sinitsyna), phatic lexical means (S. Bykovskaya), phatic strategies (V. Fedotova), speech clichés (V. Stribizhev), contactestablishing speech clichés (A. Vlasova), speech stereotypes (A. Kutkova), means of the communicative contact (Yu. Egorova), regulative speech acts (O. Egorova), metacommunicative markers (E. Pigrova), or even such independently investigated metacommunicative elements as Can you imagine that ...? you know (S. M. Croucher; L. Volkova). The aspects of research 
include communicative, functional, pragmatic, and stylistic approaches to the analysis of the processes of metacommunication and phatic interaction. However, according to Ya. Gnezdilova [4], the lack of the unified approach to the classification of metacommunicative means is partly due to the fact that emperical research studies are normally focused exclusively on one or on a few metacommunicative markers.

The purpose of this research is 1) to systematize metacommunicative questions, which belong to the group of topicalizing questions; 2) to define the spectrum of interlocutors' regulatory actions through the mediation of metacommunicative contact-establishing topicalizing questions in modern English dialogic discourse.

To reach the objective of the research and accomplish its tasks, a number of general scientific methods (deduction, induction, analysis, and synthesis) as well as methods of linguistic analysis (pragmatic, discourse, speech act, and contextual analyses) are used.

Results. One of the main metacommunicative tasks, realized at the stage of establishment of the communicative contact with the help of metacommunicative contact-establishing topicalizing questions, is the choice of the contact-establishing topic of conversation $(11,9 \%)$ [5]. A set of communicative topics at the stage of contact establishment is usually associated with the communicative situation, i. e., the set of conversational partners, their actions, motives and goals. Small talk is characterized by an extremely wide thematic palette, since almost anything in interlocutors' interests can serve as the topic of conversation. The theme for discussion can be objects of the surrounding world, spatial, temporal, cultural, information objects, phenomena, etc. It is important to note that the presentation and development of these topics usually has an anthropocentric orientation, i. e., the conversation revolves around people who become the focus of communication. Reflection of interlocutors' personality and character, way of life, sphere of activity, social status become the central communicative theme of phatic communion.

There are topics of personal and nonpersonal character. The personal topics include the following subjects: family, children, relatives and friends, health, holidays, trips, employment, studies, pets, plans for the future, etc. To the nonpersonal sphere of interlocutor belong: 1) the themes of the most general nature: weather, "random" topics related to the situation of the objective reality at the time of communication; 2) themes of social character: topical cultural events.

There is the one-sided opinion of the researchers that a universal and safe topic for the British is a commentary on the weather [8, p. 48; 9, p. 135]. It is important means for maintaining the communicative contact avoiding uncomfortable silence. The weather is usually the topic of conversation for total strangers. In addition, interlocutors are resorted to talk about the weather in cases of complete divergence of their interests or lack of common background. For example:

(1) [When I arrived at a grocery store, a jovial middle-aged woman met me at the door...]

Mary: Come, come, follow me. I'll put on the kettle and we can have a cuppa. Isn't it hot today? [She said in an attempt to put me at ease.]

Thelma: Yes, the hottest day of the year, I wouldn't be betting.

Mary: Then you must be thirsty. My name is Mary. What's yours?

Thelma: Thelma Young (R. Stokes. Thelma's Cottage, p. 82-83).

Conversation about the weather (Isn't it hot today?) is a neutral topic of interaction for total strangers who have just met in a grocery store and established the communicative contact. 
As our research has proved, comments on the weather are interrogative constructions in the form of tag-questions. The pragmatic analysis of tag-questions revealed the specifics of their functioning in the communicative process at the stage of contact establishment, i. e, they accomplish the illocutionary force of an invitation or an offer to agree with the propositional content of the affirmative part of the tagquestion, as in the example:

(2) Stranger: Hello. Lovely weather, isn't it?

Sandra: Yes, beautiful.

Stranger: American?

Sandra: Yes.

Stranger: On holiday?

Sandra: Yes (A. Ingham. Lazy Friends, p. 22).

In the above fragment the interlocutors, previously unfamiliar with each other, are faced with the problem of finding a subject of interaction in the situation of getting acquainted on the seacoast. The initiator of communication (the young writer) solves this problem easily, using one of the most neutral and typical for the British topics to establish the communicative contact - the weather ("Lovely weather, isn't it?").

The topics of conversation for interlocutors who are well acquainted with each other can be family relationships, the feelings of their relatives or close friends. As a rule, within a small talk, none of the communicative themes gets real development, details are avoided. Even if one has to talk about something negative it is pronounced in a friendly or humorous way as well as without mentioning details, because in any case the information reported is not important in itself, but as means of contact establishment. Example:

(3) [It's coming from a small television a night security guard is watching. But when he sees Billy approaching, he quickly shuts it off.]
Billy: It's okay, Joe, you can leave it on. It's no big deal.

Security Guard: No, it's okay, I don't need to watch it.

Billy: How's Meg?

Security Guard: She's good, thanks.

Billy: And the boys?

Security Guard: They're good. Everybody's good.

Billy: That's good. Night.

Security Guard: Night, Billy. That was a good season (S. Zaillian, A. Sorkin Moneyball).

The discussion of interlocutors' plans for the future, the question about their recent past, or current actions serve as a favorable ground for the further development of spoken interaction among conversational partners who know each other very well. For example:

(4) [Everyone is rushing to class. Evan hurries through the halls and finds Helen at her locker.]

Evan: Hey Helen! Hold up. Did you hear about the party tonight?

Helen: Yeah, I just heard. It sounds sweet. You're not coming, are you?

Evan: No, no, I am. That's why I came looking for you... (S. Rogen, E. Goldberg. Superbad)

The foremost topic of small talk is the conversation about interlocutors themselves. This fact is emphasized in all modern studies devoted to the study of the genre of small talk, as well as numerous manuals for mastering the maintenance of small talk, the authors of which note that this rule is based on the principle "People like to talk about themselves" [11, p. 824; 13 , p. 109]. The contact-establishing metacommunicative questions express the interlocutor's interest in the partner of communication contributing to the development of spoken interaction, as in the example:

(5) [Ringing.]

Joanna: Hello, Felicia? This is Joanna, how are you? 
Felicia: Oh my God! Joanna how are you doing? I haven't heard from you in ages.

Joanna: I am fine Felicia. How are things over there?

Felicia: I have bad news Joanna. Raul has been arrested! (M. R. Iuliano. Joanna, p. 96)

Metacommunicative contact-establishing topicalizing questions are the bearers of thematic information. Thematic information is inherent to any coherent spoken interaction. The topic of interaction occurs in the form of a macroproposition or macrostructure. Thematic information is realized through separate utterances; its deployment obeys the principle of linearity of speech, the characteristic feature of which is the global, hierarchical (vertical) organization [1; 3]. Metacommunicative topicalizing questions set the subject of dialogic discourse making the interlocutor change the topic of conversation smoothly and regulate the flow of interaction taking into account the interlocutor's character and personality traits.

Conclusions and discussion. The metacommunicative contact-establishing topicalizing questions carry out regulation at organizational, thematic and illocutionary-intentional levels. At the level of the organization of dialogic discourse with the help of topicalizing questions conversational partners regulate social relations within a certain communicative act, i. e., they establish social-etiquette contact and also affect the emotional tone of interaction, i. e., establish psychological contact. By setting social and psychoemotional parameters of a certain act of spoken interaction, topicalizing questions regulate the thematic content of interaction. Using topicalizing questions the speaker influences the listener's intentions, modifying them in accordance with their purpose, thus implementing illocutionary intentional regulation of dialogic discourse. Regulatory activity implemented via contact-establishing topicalizing questions is of cooperative nature, which is achieved through the strategy of contact establishment and its tactics. Investigation of contactestablishing metacommu-nicative topicalizing questions in modern English professional discourse may be of special scientific interest in upcoming papers.

\section{References}

1. Branco, A. U. (2004). Communication and metacommunication in human development. New York, Age publishing, 318.

2. Chkhetiani, T. D. (1987). Lingvisticheskie aspekty faticheskoy metakommunikatsii [Linguistic aspects of phatic metacommunication]. Candidate's thesis. Kyiv, KNLU, 203 [in Russian].

3. Crystal, D. (1987). Concepts of language development: a realistic perspective. Language development and disorders, 42-52.

4. Gnezdilova, Ya. (2017). Autonomous metacommunicative lexicon and its specifics in manipulative discourse. Lege artis. Language yesterday, today, tomorrow. The Journal of the University of SS Cyril and Methodius in Trnava. Warsaw: De Gruyter Open, vol. II(1), 4289. DOI:10.1515/lart-2017-0002

5. Grabovska, I. V. (2014). Metakomunikatyvni pytannia v suchasnomu anglomovnomu dialogichnomu dyskursi: semantyka i pragmatyka [Metacommunicative questions in modern English dialogic discourse: semantics and pragmatics]. Candidate's thesis. Kyiv, KNLU, 223 [in Ukrainian].

6. Ingham, A. (2010). Lazy friends. Durham, Strategic book publishing, 142.

7. Iuliano, M. R. (2004). Joanna. Maitland, Xulon press, 424.

8. Leech, G. (1983). Principles of pragmatics. London, Longman, 250.

9. Leech, G. (1977). Semantics. Harmondsworth, Penguin, 386.

10. Rogen. S., Goldberg E. (2006). Superbad.

URL:

(c) I. V. Grabovska

«International journal of philology» | «Міжнародний філологічний часопис» Vol. 10, № 1, 2019 
http://www.imsdb.com/scripts/Superbad.h tml

11. Stenstrőm,A.-B.(1988). Questions in conversation. Questions and questioning. Berlin; New York, Mouton de gruyter, 304-326.

12. Stokes, R. (2006). Thelma's cottage. New York, Lulu, 184.
13. Wagner, K. A. (1977). Sprechstrategie - illokution versus sprechakt-Illokution. Deutsche sprache. N 5. 126-140.

14. Zaillian, S., Sorkin A. (2011). Moneyball.

URL: https://www.scriptdelivery.net/source/reso urces/screenplays/moneyballscreenplay.pdf

\section{МЕТАКОМУНІКАТИВНІ КОНТАКТОВСТАНОВЛЮВАЛЬНІ ПИТАННЯ- ТОПІКАЛІЗАТОРИ В СУЧАСНОМУ АНГЛОМОВНОМУ ДІАЛОГІЧНОМУ ДИСКУРСІ}

\section{І. В. Грабовська}

Анотація. У статті розглядається стадія встановлення мовленнєвого контакту. Визначаються фоункціонально-семантичні особливості контактовстановлювальних метакомунікативних питань як засобу організації діалогічного дискурсу. Розроблено спектр метакомунікативних контактовстановлювальних тем, які реалізуються за допомогою питаньтопікалізаторів у сучасному англомовному діалогічному дискурсі. Метакомунікативні контактовстановлювальні питання-топікалізатори регулюють хід інтеракції, забезпечують зворотний зв'язок у процесі спілкування.

Ключові слова: метакомунікативне контактовстановлювальне питаннятопікалізатор, діалогічний дискурс, інтеракція, мовленнєвий контакт, фратичний дискурс 